\title{
Cryptococcosis by Cryptococcus gattii in immunocompetent goats in Spain and review of the literature
}

\author{
Criptococose causada por Cryptococcus gattii em cabras \\ imunocompetentes na Espanha e revisão de literatura \\ Josep Maria Torres-Rodríguez', Miguel Hermoso de Mendoza², \\ Eidi Alvarado-Ramírez' \& Gemma Segura-Roca'
}

\begin{abstract}
Cryptococcus neoformans has been described for years as a species causing spontaneous mycosis in a great variety of animals. The new species $C$. gattii has been described as an agent of animal cryptococcosis mainly in Australia, but it has been found also in many parts of the world. The main group of animals suffering those natural infections are mammals, but also birds, reptiles and some invertebrates have suffered cryptococcosis. Usually the infections are sporadic and occasional, but some epidemic outbreaks have been reported affecting a high number of animals. In 1998 the isolation of $C$. gattii was reported by the first time in Europe in 5 epidemic outbreaks of cryptococcosis in goats grazing freely in west Spain grasslands. In all outbreaks, mycological studies were possible from samples obtained on necropsy of some animals dead during the epidemic. Animals belonged to various milking breeds and were grazing with variable status of health and husbandry. Goats affected by cryptococcosis showed similar respiratory symptoms, consisting in mucopurulent nasal discharge, cough, dyspnea and progressive cachexia, causing death in a period of 2 to 4 weeks. In three outbreaks many animals also showed ataxia, midriasis, blindness and progressive paralysis. Clinical prevalence varied from 2 to $12 \%$ in the different outbreaks. It is evident that in spite of the great amplitude of geographical distribution observed for $C$. gattii, this species has a limited presence, possibly restricted to determined habitats, as that of infection of goats flocks in Spain. Veterinarians must be concerned about Cryptococcosis in grazing animals. This finding introduced new elements connected to the epidemiology and ecology of Cryptococcus gattii.
\end{abstract}

Key words: cryptococcosis, Cryptococcus gattii, goats, immunocompetent, outbreaks, Spain.

\section{RESUMO}

Cryptococcus neoformans tem sido descrito desde longa data, como uma espécie causadora de micose espontânea em uma grande variedade de animais. A nova espécie, $C$. gattii, tem sido isolada de casos de criptococose animal principalmente na Austrália, mas também em várias partes do mundo. Os mamíferos constituem o grupo de animais que mais sofrem infecção natural, mas também pássaros, répteis e alguns invertebrados têm sido acometidos por criptococose. Usualmente as infecções são esporádicas e ocasionais, mas alguns surtos epidêmicos têm sido relatados como afetando um grande número de animais. Em 1998, C. gattii foi isolado pela primeira vez na Europa em 5 surtos epidêmicos de criptococose em cabras que pastavam livremente em propriedades situadas no oeste da Espanha. Em todos surtos, o diagnóstico micológico foi realizado com das amostras obtidas a partir da necropsia de alguns animais mortos durante os surtos. Estes animais pertenciam a várias raças leiteiras criadas em diferentes regimes sob o ponto de vista do status sanitário e de manejo. As cabras com criptococose apresentavam sinais clínicos respiratórios similares, que consistiam de descarga nasal mucopurulenta, tosse, dispnéia e caquexia progressiva, os quais causavam a morte num período de 2 a 4 semanas. Em três surtos, muitos animais também apresentaram ataxia, midríase, cegueira e paralisia progressiva. A prevalência clínica variou de 2 a $12 \%$ nos diferentes surtos. Parece evidente que, apesar da grande amplitude da distribuição geográfica do $C$. gattii, esta espécie tem uma presença possívelmente restringidas a determinados habitats, como no caso das infecções nos rebanhos de cabras na Espanha. Os veterinários devem estar atentos para a possibilidade de ocorrência de criptococose em animais criados a campo. Estes achados contribuem, com a apresentação de novos elementos, para uma melhor compreensão da epidemiologia e ecologia do Cryptococcus gattii.

Descritores: criptococose, Cryptococcus gattii, cabras, imunocompetente, surtos, Espanha. 


\section{INTRODUCTION}

\section{EPIDEMIOLOGY}

1. Habitat and source of infection

2. Factors favouring animal infection

\section{CRYPTOCOCCOSIS IN ANIMALS}

\section{Domestic animals}

\section{Pigeons}

\section{Wild birds}

\section{C7RYPTOCOCCUS GATTII IN GOATS}

\section{Antecedents}

\section{Outbreaks}

\section{DISCUSSION AND CONCLUSIONS}

\section{INTRODUCTION}

Cryptococcus neoformans has been described for years as a species causing spontaneous mycosis in a great variety of animals. Recently $C$. gattii has been considered as a different species from $C$. neoformans, to which it was related as a variety with different biochemical and physiological characteristics and possibly with different pathogenetic treats $[22,35,36]$.

The new species $C$. gattii has been described as an agent of animal cryptococcosis mainly in Australia, but it has been found also in many parts of the world [4].

The main group of animals suffering those natural infections are mammals, but also birds, reptiles and some invertebrates have suffered cryptococcosis [28]. Usually the infections are sporadic and occasional, but some epidemic outbreaks have been reported affecting a high number of animals [21,38].

Actually inhalation of environment yeasts may cause infections of the upper and lower respiratory tract as well as visceral dissemination, depending on the virulence of the infectious strain and the health status of the animal. Penetration through the skin or mucosae and development of local lesions, also have been described in different animals although less frequently [9].

\section{EPIDEMIOLOGY}

\section{Habitat and source of infection}

C. neoformans has been isolated everywhere from nature, varying its prevalence and abundance [5]. Less frequently and with a strait geographical distri- bution, $C$. gattii also has been isolated mainly from detritus of trees, specially from Eucalyptus [14,18,24]. For those reasons it is not difficult to explain the high variety of animals that become infected by the exposition to that environment yeast (Table 1). It is very probable that another animal species, specially the wild ones, could suffer cryptococcosis without a diagnosis made until now.

In many occasions the strains of Cryptococcus isolated from nature have not been adequately studied in order to differentiate the two species and their serotypes.

Another aspect of interest is the finding of asymptomatic dogs and cats carriers of $C$. gattii colonizing their nasal sinus [12]. This situation seems to be a risk factor for a progressive cryptococcosis in those animals [13].

\section{Factors favouring animal infection}

Factors that favour infection by Cryptococcus have been studied mainly in dogs and cats. Previous infection by FIV (feline immunodeficiency virus), a lentivirus similar to human HIV, may explain the high susceptibility of this species mainly to $C$. neoformans [31]. Another example is provided by the co-infection of FeLV (feline leukaemia virus) and the isolation of C. neoformans var. gattii from a siamese cat with disseminated disease, in a case reported in Brazil [16].

The abundance of this yeast in soil samples may suppose a higher prevalence of cryptococcosis in animals with smelling or herbivorous habits, more expo- 


\begin{tabular}{|c|c|c|}
\hline Mammals & Birds & Others \\
\hline Cats & Columbiformes (Pigeons) & Reptiles \\
\hline Dogs & Kiwi & Insects (cockroach, lepidopters) \\
\hline Cows/Buffalos & $\begin{array}{l}\text { Psittaciformes (Charmosyna } \\
\text { papou, Lorius lory, Trichoglossus } \\
\text { goldiei, Psittacula krameri, } \\
\text { Psittacus erithacus) }\end{array}$ & Acarus \\
\hline Goats & Anseriformes (ducks, swans) & \\
\hline Horses & Cockatoo & \\
\hline Pigs & Magpie & \\
\hline Hamsters & Crow & \\
\hline Rodents (rat, mouse) & Paroquet & \\
\hline Primates (Mangabey) & Canary & \\
\hline Camelids (Ilama) & Swallow & \\
\hline Guepards (cheeta) & Krestel & \\
\hline Fox & Buzzard & \\
\hline \multicolumn{3}{|l|}{ Ferrets } \\
\hline \multicolumn{3}{|l|}{ Algalia (civet) } \\
\hline \multicolumn{3}{|c|}{ Fox of desert (Fennecus zerda) } \\
\hline \multicolumn{3}{|l|}{ Marmots } \\
\hline \multicolumn{3}{|l|}{ Koalas } \\
\hline \multicolumn{3}{|l|}{ Dolphins } \\
\hline Bats & & \\
\hline
\end{tabular}

sed to yeast inhalation or by eating contaminated vegetable with cryptococcus.

Unusual high number of infections by $C$. gattii in wildlife animals, affecting different species, including dogs and cats, as well as humans, occurred in Vancouver (British Columbia, Canada) after 1999 [10]. In domestic animals the infections were related with the easiness of acquiring Crytptococcosis due to their street activity and living near crowded commercial malls [11].

\section{CRYPTOCOCCOSIS IN ANIMALS}

\section{Domestic animals}

Among domestic animals, cats and dogs seems to be the most commonly affected by cryptococcosis, although permanent and closer contact with their owners is possibly the cause of an early detection of their health deterioration, and a veterinary examination. This would explain the higher number of diagnosis of crypto- coccosis in that group of animals. In other domestic animals like cows, horses, pigs and goats, the diagnosis is done when epidemic outbreaks occur and after necropsy and mycological search of obtained tissues [34].

Both species of Cryptococcus have been isolated from those animals, greatly depending on geographic area and the available veterinary facilities. On the other hand, diagnosis made in wild animals, like guepards, foxes, primates, dolphins and other more, have been done in zoological gardens or aquarium under veterinary supervision.

\section{Pigeons}

The relation between Cryptococcus neoformans and birds is very narrow since it was demonstrated in Europe in 1974 that pigeon excrements are an important reservoir of that yeast [37]. The isolation of that yeast in pigeon faeces remains a study motive to know the epidemiology of cryptococcosis around the world. 
C. neoformans var. grubbii (serotype A) was isolated in the city of Barcelona, northwest of the Iberic Peninsula, on Mediterranean Sea coast, with a high population density (316 inhabitants per hectare) and a traditional abundance of pigeons, in $17 \%$ out of 303 collected samples [29]. All isolated samples were of the molecular standard VNI [27]. It is interesting to note that after an in vitro sensibility study at least 4 of those environmental strains showed natural resistance to fluconazol, which implicates that primary infection in humans or animals with isolates resistant to azoles could occur.

Similar results have been found in samples from the city of Seoul (Korea) [6], where 8 from 72 dry faeces samples of pigeons were positive to $C$. neoformans var. grubbii (serotype A), with the same molecular standard.

In the state of Goias (Brazil) has been also reported the isolation of $C$. neoformans var. grubii in $20 \%$ of pigeons faeces and in 14\% of Eucalyptus samples, though in that case no resistance to antifungi were detected, including fluconazol [20].

\section{Wild birds}

Abegg et al. in Rio Grande do Sul state (southern Brazil) [1] has been recently reported that 38 faeces samples out of 59 different birds captive in zoo were positive to $C$. neoformans but only Psittaciformes. In that case a diversity was demonstrated because $89 \%$ of isolated samples were from variety grubbii VNI and $13 \%$ were from C. gattii serotype B, molecular standard VGI.

In São Paulo (Brazil) an epidemic outbreak was described in different species of Psittacides which died of disseminated cryptococcosis. In 7 studied animals, C. gattii serotype $\mathrm{B}$, resistant to fluconazol was isolated [33].

That yeast has been isolated from other birds around the world. In Egypt Cryptococcus neoformans was isolated in swallow faeces [26], in Massachussets (USA) a zoonotic transmission of Cryptococcus neoformans has been evidenced by a cockatoo [25,30], and in Holland the same transmission was proved by a magpie (in this last case the transmission to an immunocompetent patient was described) [23]. In New Zealand, a case of disseminated cryptococcosis was reported in a kiwi [19] by $C$. gattii; in Italy, $C$. neoformans was isolated from canary faeces [8] and, in Germany, C. neoformans has been observed in paroquet excrements [39, 40]. Also, in New York (Manhattan), fungical diseases have been reported, including crytococcosis in Anse- riformes (ducks and swans) [32], while in India Cryptococcus neoformans was isolated in faeces of crows [17].

Recently in Southeast of Italy, C. neoformans var. grubii has been isolated from cloacae and faecal samples of birds of prey including Falco tinnunculus and Buteo buteo [3].

\section{CRYPTOCOCCUS GATTII IN GOATS}

\section{Antecedents}

In 1998 the isolation of $C$. gattii was reported by the first time in Europe [2] in at least 5 epidemic outbreaks of cryptococcosis in goats grazing freely in west Spain grasslands. This finding introduced new elements connected to the epidemiology of animal cryptococcosis and the ecology of $C$. gattii.

Between 1991 and 1995 some epidemic outbreaks were reported affecting goats in different fields of the Province of Caceres (Extremadura), located at the Southwest Spain, in the border of Portugal. The north zone of that province is montainous, while the rest of the province is a fertile plain bathed by Tajo River and its affluents, with important development of agriculture and livestock.

Mycological studies were done in 5 different epidemic outbreaks affecting goats in samples obtained by necropsy. Figure 1 shows the zones were outbreaks occurred.

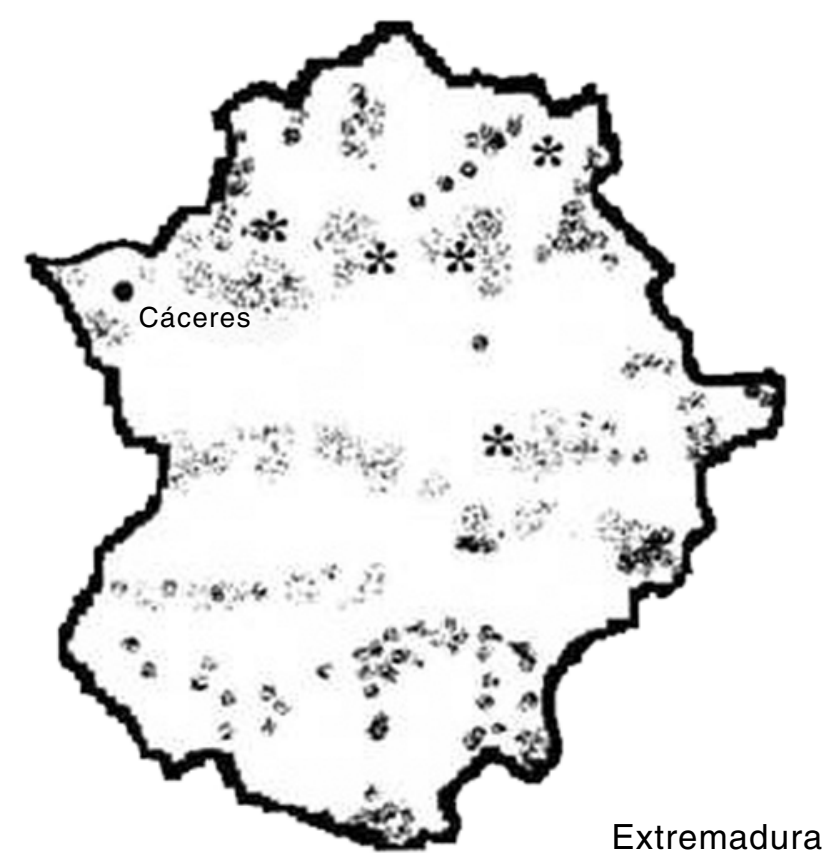

Figure 1. Map of the Province of Extremadura (southeast of Spain). Asterisks show the zones where cryptococcosis outbreaks occurred. The shadow zones correspond to Eucalyptus plantations. 
The outbreak affected goats, most of them completely healthy, belonged to various milking breeds free grazing in different fields of Cáceres.

In one outbreak animals with other diseases were observed (brucelosis, paratuberculosis). Animals affected by cryptococcosis showed similar respiratory symptoms in all outbreaks, consisting in mucopurulent nasal discharge, cough, dispnea and progressive caquecsy, causing death in a period of 2 to 4 weeks. In three outbreaks many animals also showed ataxia, midriasis, blindness and progressive paralysis. Clinical prevalence varied from 2 to $12 \%$ in the different outbreaks.

All animals affected by cryptococcosis developed a serious pneumonia with signals of consumption and in many cases neurological signs (Figure 2). Total mortality in each flock is presented in Table 2, being the higher of $12 \%$.

Various animals were submitted to necropsy taking tissue samples in 6 of them for histological analysis and mycological culture (Figure 3).

In cultures of 13 samples grew abundant colonies of yeasts identified as Cryptococcus neoformans. Abundant encapsulated yeasts were also found in histological sections of lung and brain (Figure 4).

Cultures with CGB (Canavanine, Glycin, Bromotimol blue) and the assimilation of proline and triptophan let classified them as $C$. neoformans var. gattii. The serological test ${ }^{1}$ showed that all of the isolates corresponded to serotype B. Molecular typed by RAPD technique classified the isolates as VGNI, standard according to Meyer et al. [26].

Attempts trying to isolate the yeast from the environment at the zone where goats were grazing resulted unfruitful. The grazing fields characteristics were very different but plantations of Eucalyptus forests were present in most cases. These trees were introduced between 1955 and 1970, from France seed fields.

\section{Outbreaks}

The detailed and chronological description of the studied outbreaks, detected and diagnosed by the Caceres Faculty of Veterinary is as follows:

Outbreak 1. (October 23, 1990). Location: Madrigal de la Vera, $167 \mathrm{~km}$ from Caceres. Flock of 140 grazing goats. No pigeons in the farm.

The process began one year before with a high clinical prevalence according to the anamnesis, though not quantified.
Passive agglutination with latex ${ }^{2}$ for detection of capsular antigen of Cryptococcus performed in 50 sera showed $12 \%$ of prevalence. Clinical signs were respiratory with pneumonia and caquecsy, without neurological symptoms, mortal evolution.

Two auxanographically distinct strains of $C$. neoformans were isolated in lung tissue, mediastinic ganglia and traqueal exudate, as well as in intestinal content, faeces and mesenteric ganglia from two animals. Culture of samples of CNS were negative. An environmental scanning also was negative.

Outbreak 2. (April 14, 1991). Location: Madroñera, $61 \mathrm{~km}$ from Caceres. Flock of 250 grazing goats. Clinical prevalence of 2\%. Symptoms: respiratory, ataxia, progressive caquecsy and death. Presence of abundant pigeons.

The process presented a one year evolution. Health of flock was poor with animals affected by brucelosis and paratuberculosis.

Cryptococcosis presented also neurological symptoms, confirming the diagnosis by microscopy and positive culture of samples from lung and CNS. Strains of one auxanographic type were isolated.

Outbreak 3. (January 20, 1994). Location: Pescueza, $78 \mathrm{~km}$ from Caceres. Flock of 300 grazing goats. Clinical prevalence of $10 \%$, subacute or chronic pneumonia, caquecsy of mortal evolution. No pigeons in the zone but presence of eucaliptus.

Microscopic observation and isolation of Cryptococcus neoformans in lungs. One auxanographic type detected.

Outbreak 4. (March 15, 1994). Location: Serradilla, $70 \mathrm{~km}$ from Caceres. Flock of 200 grazing goats. Prevalence not determined. Pneumonia process, caquecsy and neurological symptoms (ataxia and mortal progressive paralysis). No pigeons or eucaliptus in the zone.

Microscopic observation and isolation of Cryptococcus neoformans in lungs and CNS. One auxanographic type detected.

Outbreak 5. (May 03, 1994). Localización: Casas de Millán, $53 \mathrm{~km}$ from Caceres. Flock of 120 grazing goats. Clinical prevalence of 2,5\%, presenting pneumonic process, caquecsy and neurological symptoms (ataxia, midriasis and blindness). Mortal evolution in 15-20 days. Presence of abundant pigeons in the farm.

Microscopic observation and isolation of $C$. neoformans in lungs, CNS and liver. One auxanographic type detected. 
Torres-Rodríguez J.M., Mendoza M.H., Alvarado-Ramírez E. \& Segura-Roca G. 2006. Cryptococcosis by Cryptococcus gattii in immunocompetent goats in Spain and review of the literature.

Acta Scientiae Veterinariae. 34: 245-253.

\begin{tabular}{|c|c|c|c|c|}
\hline $\begin{array}{l}\text { Year of the } \\
\text { outbreak }\end{array}$ & $\begin{array}{l}\text { Location of the } \\
\text { infection (City) }\end{array}$ & $\begin{array}{l}\text { Number of } \\
\text { animals of } \\
\text { the flock }\end{array}$ & $\begin{array}{c}\text { Clinical } \\
\text { Prevalence } \\
(\%)^{\star}\end{array}$ & $\begin{array}{c}\text { DNA } \\
\text { fingerprinting }\end{array}$ \\
\hline 1990 & Madrigal de la Vera & 140 & 12 & VGNI \\
\hline 1991 & Madroñera & 250 & 2 & VGNI \\
\hline 1994 & Pescueza & 300 & 10 & VGNI \\
\hline 1994 & Serradilla & 200 & unknown & VGNI \\
\hline 1994 & Casas de Millán & 120 & 2,5 & VGNI \\
\hline
\end{tabular}

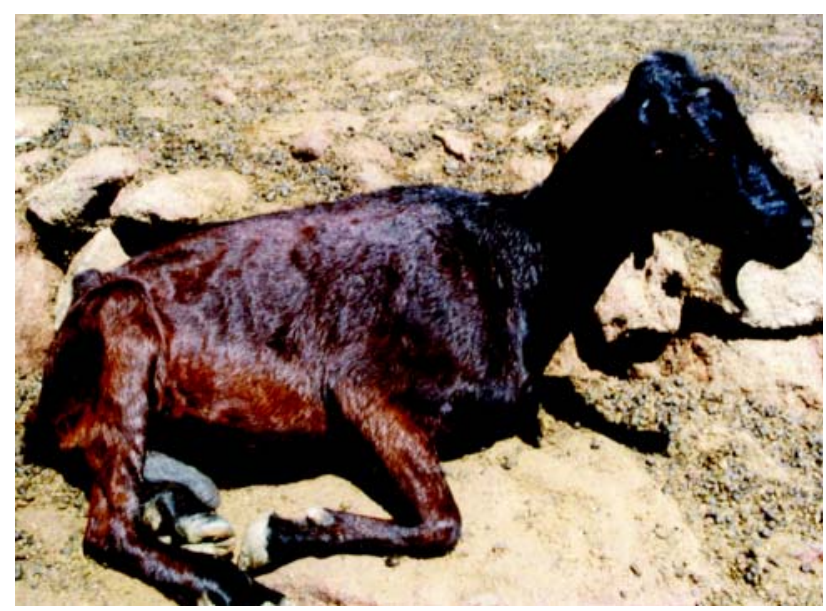

Figure 2. Goat affected by pulmonar consumptive cryptococcosis.

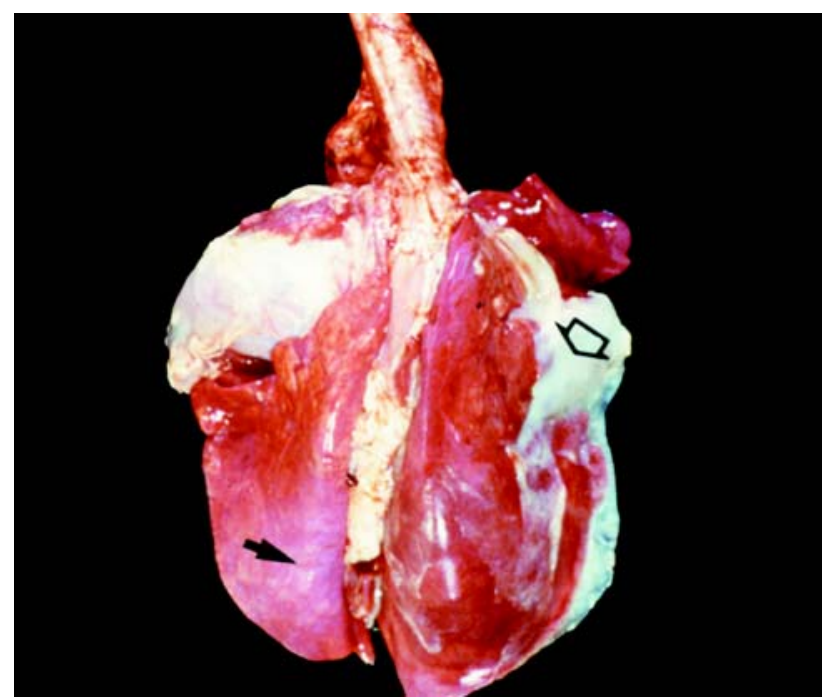

Figure 3. Anatomical piece obtained in the necropsy of a goat dead by cryptococcosis. Arrows show pleuritis zones.

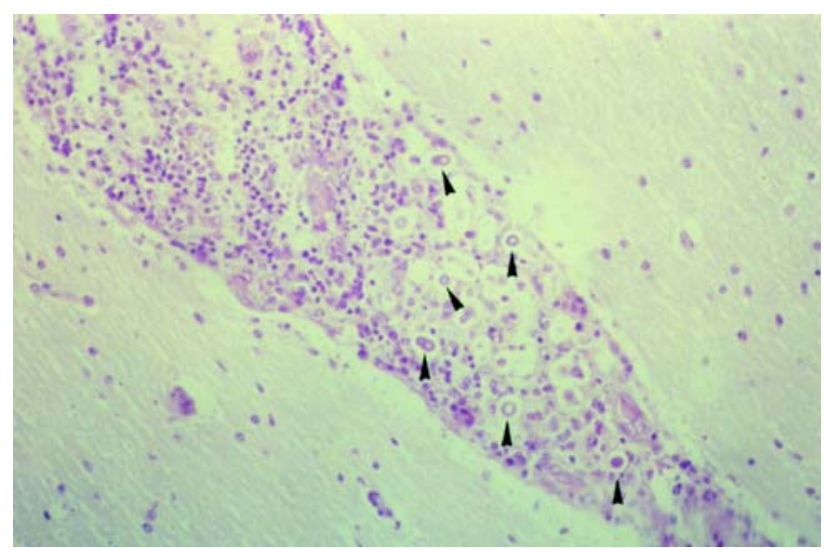

Figure 5. Histological section of a brain of a goat dead by cryptococcosis. Arrows show abundant encapsulated yeasts. with capsules withdrawn by the dye. 


\section{DiscuSSION AND CONCLUSIONS}

The mycological analysis of 13 isolated strains of those outbreaks showed the variety gattii (C. gattii), serotype B [25], suggest that $C$. gattii was present in the environment of the affected animals in an endemic form. Nevertheless, the cultures of environment samples (soil, pigeon dejection, eucalyptus debries) were negative for this fungus. On the other hand, vast majority of goats with cryptococcosis seemed to be previously healthy, suggesting a high virulence of the isolated strains.

The relationship between $C$. gattii and Eucalyptus camaldulensis in Australia, and other species of Eucalyptus (E. tereticornis, E. globulus, etc) in other countries, suggests that probably the yeasts that infected the goats were in the Eucalyptus detritus near the animals, persisting in the environment during long time in a large zone.

The respiratory symptoms support the idea that the goats suffered an air-borne infection, probably with abundant and repetitive inocule. Although it is known that this is the main way of infection of Cryptococcus, mucous or digestive inoculation can not be rejected, as some animals presented digestive lesions and $C$. gattii was isolated in a sample of intestinal content of one goat.

Information obtained from the Infectious Diseases Departments of the main Hospitals of Cáceres, confirmed that human cases of cryptococcosis were rare without an increase in its frequency. The scarce isolates of Cryptococcus cultured from human samples were not typed.

More recently the first case of human cryptococcosis by $C$. gattii was reported in a patient resident in Spain [7], in a different and distant region, in southeast of the Peninsula (Alicante), with Mediterranean weather. In that case isolation of this species from environmental and soil samples, bird faeces or vegetal detritus (Eucalyptus was not present) was unfruitful.
The authors marked as uncontrolled antecedent the contact with a parrot belonging to the neighbours.

Between 1998 and 2000 in different zones of Catalunya (Northeast of the Peninsula), 132 samples of leaves, cortex, flowers and material from holes of Eucalyptus (E. camaldulensis, E. globulus and E. darympleana) were cultured without obtaining isolation of $C$. gattii or $C$. neoformans, but other no pathogenic species like $C$. laurentii and $C$. albidus were isolated [29].

In other parts of the world, different from Australia, isolation of $C$. gattii serotype B has been possible from nature linked to the presence of Eucalyptus, as in Cundinamarca (Colombia) where this yeast was isolated in $27,5 \%$ out of 167 samples of that tree, all of them of mating type a [15].

It is evident that in spite of the great amplitude of geographical distribution observed for $C$. gattii, this species has a limited presence, possibly restricted to certain habitats, as that those where the goats grazing.

In places different from those where $C$. gattii seems to be endemic, it is probable that animals with cryptococcosis become infected by $C$. neoformans from soil contaminated with a high number of yeasts.

Veterinarians must be concerned about Cryptococcosis in grazing animals. Health authorities must supply the adequate resources to perform a fast and accurate mycological diagnosis, as well as epidemiology analysis to know the actual prevalence of this disease in different geographical areas of the world. That information will help to design useful methods for controlling the disease.

\section{SOURCES AND MANUFACTURERS}

${ }^{1}$ Iatron Labs Inc. Tokyo, Japan.

${ }^{2}$ Pastorex Crypto-latex. Bio-Rad Laboratories, SA. Alcobendas, Madrid 28109, Spain.

\section{REFERENCES}

1 Abegg M.A., Cella F.L. \& Faganello J. 2006. Cryptococcus neoformans and Cryptococcus gattii isolated from the excreta of psittaciformes in a southern Brazilian zoological garden. Mycopathologia. 161: 83-91.

2 Baró T., Torres-Rodríguez J.M., De Mendoza M.H., Morera Y. \& Alía C. 1998. First identification of autochthonous Cryptococcus neoformans var. gattii isolated from goats with predominantly severe pulmonary disease in Spain. Journal of Clinical Microbiology. 36: 458-461.

3 Cafarchia C., Romito D., Latta R., Camarda A., Montagna T. \& Otranto D. 2006. Role of birds of prey as carriers and spreaders of Cryptococcus neoformans and other zoonotic yeasts. Medical Mycolology. 44: 485-492.

4 Callejas A., Ordoñez N., Rodríguez M.C. \& Castañeda E. 1998. First isolation of Cryptococcus neoformans var. gattii serotype C, from the environment in Colombia. Medical Mycology. 36: 341-344. 
Torres-Rodríguez J.M., Mendoza M.H., Alvarado-Ramírez E. \& Segura-Roca G. 2006. Cryptococcosis by Cryptococcus gattii in immunocompetent goats in Spain and review of the literature.

Acta Scientiae Veterinariae. 34: 245-253.

5 Casadevall A. \& Perfect R.J. 1998. Cryptococcus and cryptococcosis. Washington. ASM Press. American Society of Microbiology.

6 Chee H.Y. \& Lee K.B. 2005. Isolation of Cryptococcus neoformans var. grubii (serotype A) from pigeon droppings in Seoul, Korea. Journal of Microbiology. 43: 469-472.

7 Colom M.F., Frasés S., Ferrer C., Jover A., Anfreu M., Réus S., Sánchez M. \& Torres-Rodríguez J.M. 2005. First case of human cryptococcosis due to Cryptococcus neoformans var. gattii in Spain. Journal of Clinical Microbiology. 43: 3548-3550.

8 Criseo G., Bolignano M.S., De Leo F. \& Staib F. 1995. Evidence of canary droppings as an important reservoir of Cryptococcus neoformans. Zentralblatt Fuer Bakteriologie. 282: 244-254.

9 Dora J.M., Kelbert S., Deutschendorf C., Cunha V.S., Aquino V.R., Santos R.P. \& Goldani L.Z. 2006. Cutaneous cryptococcosis due to Cryptococcus gattii in immunocompetent hosts: case report and review. Mycopathologia. 161: $235-238$.

10 Duncan C.G., Stephen C. \& Campbell J. 2006. Evaluation of risk factors for Cryptococcus gattii infection in dogs and cats. Journal of American Veterinary Medical Association. 228: 377-382.

11 Duncan C., Schwantje H., Stephen C., Campbell J. \& Bartlett K. 2006. Cryptococcus gattii in wildlife of Vancouver Island, British Columbia, Canada. Journal of Wildlife Diseases. 42:175-178.

12 Duncan C., Stephen C., Lester S. \& Bartlett K. 2005. Sub-clinical infection and asymptomatic carriage of Cryptococcus gattii in dogs and cats during an outbreak of cryptococcosis. Medical Mycology. 43: 511-516.

13 Duncan C., Stephen C., Lester S. \& Bartlett K. 2005. Follow-up study of dogs and cats with asymptomatic Cryptococcus gattii infection or nasal colonization. Medical Mycology. 43: 663-666.

14 Ellis D. \& Pfeiffer T.J. 1990. Natural habitat of Cryptococcus neoformans var. gattii. Journal of Clinical Microbiology. 28: 1642-1644.

15 Escandon P., Quintero E., Granados D., Huérfano S., Ruíz A. \& Castañeda E. 2005. Isolation of Cryptococcus gattii, serotype B from detritus of Eucalyptus trees in Colombia. Biomedica. 25: 390-397.

16 Ferreiro L., Loretti A.P., Appelt C.E. \& Oliveira F.M. 2001. Disseminated cryptococcosis caused by Cryptococcus neoformans var. gattii in an immunocompromised siamese cat: a case report. [MV.029]. In: Resumos do III Congresso Brasileiro de Micologia (Águas de Lindóia, Brasil). p.129.

17 Gokulshankar S., Ranganathan S., Ranjith M.S. \& Ranjithsingh A.J. 2004. Prevalence, serotypes and mating patterns of Cryptococcus neoformans in the pellets of different avifauna in Madras, India. Mycoses. 47: 310-314.

18 Gugnani H.C., Mitchell T.G., Litvintsera A.P., Lengeler K.B., Heitman J., Kumar A., Basu S. \& Paliwal-Joshi. 2005. Isolation of Cryptococcus gattii and Cryptococcus neoformans var. grubii from the flowers and bark of Eucalyptus trees in India. Medical Mycology. 43: 565-569.

19 Hill F.I., Woodgyer A.J. \& Lintott M.A. 1995. Cryptococcosis in a North Island brown kiwi (Apteryx australis mantelli) in New Zealand. Journal of Medical \& Veterinary Mycology. 33: 305-309.

20 Kobayashi C., Souza L., Fernández O., Brito S., Silva A., Sousa E. \& Silva M. 2005. Characterization of Cryptococcus neoformans isolated from urban environmental sources in Goiânia, Goiás, Brazil. Revista do Instituto de Medicina Tropical de São Paulo. 47: 203-207.

21 Krockenberger M.D., Candfield P.J. \& Malik R. 2003. Cryptococcus neoformans var gattii in the koala (Phascolarcus cinereus): a review of 43 cases of cryptococcosis. Medical Mycology. 41: 225-234.

22 Kwon-Chung K.J., Boekhout T. \& Fell J.W., 2002. Proposal to conserve the name Cryptococcus gatti against $C$. hondurianus and C. bacillisporus (Basidiomycota, Hymenomycetes, Tremenomycetidae). Taxon. 51: 805-806.

23 Lagrou K., Van Eldere J., Keuleers S., Keuleers S., Hagen F., Merckx R., Verhaegen J., Peetermans W.E. \& Boekhout T. 2005. Zoonotic transmission of Cryptococcus neoformans from a magpie to an immunocompetent patient. Journal of Internal Medicine. 257: 385-388.

24 Lazera M.S., Wanke B. \& Nishikawa M.N. 1993. Isolation of both varieties of Cryptococcus neoformans from saprophytic source in the city of Rio de Janeiro. Brazil. Journal of Medical \& Veterinary Mycology. 31: 449-454.

25 Lester S.J., Kowalewich N.J., Bartlett K.H., Krockenberger M.B., Fairfax T.M. \& Malik R. 2004. Clinicopathologic features of unusual outbreak of Cryptococcosis in dogs, cats, ferrets and a bird: 38 cases (January to July 2003). Journal of American Veterinary Medical Association. 225: 1716-1722.

26 Mahmoud Yehia A.-G. 1999. First environmental isolation of Cryptococcus neoformans var. neoformans and var. gatti from the Gharbia Governorate, Egypt. Mycopathologia. 148: 83-86.

27 Meyer W., Castaneda A., Jackson S., Huynh M. \& Castaneda E. 2003. Ibero American Cryptococcal Study Group. Molecular typing of Ibero American Cryptococcus neoformans isolates. Emerging Infectious Diseases. 9: 189-195. 
Torres-Rodríguez J.M., Mendoza M.H., Alvarado-Ramírez E. \& Segura-Roca G. 2006. Cryptococcosis by Cryptococcus gattii in immunocompetent goats in Spain and review of the literature. Acta Scientiae Veterinariae. 34: 245-253.

28 Miller W.G., Padhye A.A., van Bonn W., Jensen E., Brandt M.E. \& Ridgwa S.H. 2002. Cryptococcosis in a bottelnose dolphin (Turiopsis truncates) caused by Cryptococcus neoformans var gattii. . Journal of Clinical Microbiology. 40: $721-724$.

29 Morera-López Y., Torres-Rodríguez J.M., Jiménez-Cabello T., Baró-Tomás T., Alía-Aponte C. \& Lázera M. 2005. DNA fingerprinting pattern and susceptibility to antifungal drugs in Cryptococcus neoformans variety grubii from Barcelona city and rural environmental samples. Mycopathologia. 169: 9-14.

30 Nosanchuk J.D., Shoham S., Fries B.C., Shapiro D.S., Levitz S.M. \& Casadevall A. 2000. Evidence of zoonotic Transmission of Cryptococcus neoformans from a Pet Cockatoo to an immunocompromised. Annals of Internal Medicine. 132: $205-208$.

31 O’Brien C.R., Krockenberger M.B., Wigney D.I., Martin P. \& Malik R. 2004. Retrospective study of feline and canine cryptococcosis in Australia from 1981 to 2001: 195 cases. Medical Mycology. 42: 449-460.

32 Pollock C. 2003. Fungal diseases of Columbiformes and Anseriformes. Veterinary Clinics of North America: Exotic Animal Practice. 6: 351-361.

33 Raso T.F., Werter K., Miranda E.T. \& Mendez-Giannini M.J. 2004. Cryptococcosis outbreak in psittacine birds in Brazil. Medical Mycology. 42: 355-362.

34 Riley C.B., Bolton J.R., Mills J.N. \& Thomas J.B. 1992. Cryptococcosis in seven horses Australian Veterinary Journal. 69: 135-139.

35 Sorell T.C. 2001. Cryptococcus neoformans var. gattii. Medical Mycology. 39: 155-168.

36 Speed B. \& Dunt D. 1995. Clinical and host differences between infections with the two varieties of Cryptococcus neoformans. Clinical Infectious Diseases. 21:28-34.

37 Swinne-Desgain D. 1974. The pigeon as reservoir of Cryptococcus neoformans. Lancet. 842-843.

38 Torres-Rodríguez J.M., Morera Y. \& Baró-Tomás, T. 2004. Stpontaneous infection of animals with Cryptococcus neoformans and Cryptococcus gattii. Mikologia Lekarska. 11: 303-307.

39 Weber A. \& Schafer R. 1991. The occurrence of Cryptococcus neoformans in fecal samples from birds kept in human living areas. Berliner und Munchener Tierarztliche Wochenschrift. 104: 419-421.

40 Wegener H.H. \& Staib F. 1983. Fatal cryptococcosis in a bird fancier. A clinical case report on pathology, diagnosis and epidemiology of cryptococcosis. Zentralblatt Fuer Bakteriologie, Mikrobiologie und Hygiene. 256: 231-238. 